\title{
Aging: well being and development in elderly
}

\section{Pallavi and Tulika Borah}

Received: 15.06.2020; Accepted: 30.11 .2020

See end of the paper for authors' affiliations

\section{Pallavi}

Department of Human Development and Family Studies, Assam Agricultural

University, Jorhat (Assam) India Email : brar.pallavi1996@gmail. com
ABSTRACT : The aim of the present study is to introduce the well- being and aging development during old age. In old age peoples are not more productive as in early stage of life. They need others support for doing some activities. Sometimes they feel stressed and depressed about that. The current study indicated that physical condition of old age person, sociodemographic factors, social network characteristics, and activity level all seem to affect subjective well-being in later life. In the present study discuss several different forms of well-being that play a vital role in the lives of elderly and it helps them to live longer and safer.

KEY WORDS: Aging, Development, Elderly, Healthy-ageing, Well-being

- HOW TO CITE THIS PAPER : Pallavi and Borah, Tulika (2020). Aging: well being and development in elderly. Asian J. Home Sci., 15 (2) : 434-437, DOI: 10.15740/HAS/AJHS/15.2/434-437. Copyright@ 2020: Hind Agri-Horticultural Society. 